\title{
Review \\ Screening of citrus rootstocks for salt tolerance in semi-arid climates - A review
}

\author{
Awtar SingH ${ }^{1)}$, M. L. SAINI ${ }^{2)}$ and R. K. BEHL ${ }^{2)}$ \\ ${ }^{1)}$ National Research Centre for Citrus, Post Bag No. 464, Shankar Nagar P.O. Nagpur - 440010 Maharashtra, India. \\ ${ }^{2}$ Department of Plant Breeding CCS HAU Hisar- 125004 (India)
}

\begin{abstract}
Generally, Citrus species are grown in tropical and sub-tropical climates where the rainfall is limited, so irrigation is required to sustain the plant growth, creating salinity problems. Citrus species are very sensitive to salinity. Salinity affects seed germination, plant growth, fruit yield and it causes nutrient imbalances in the plants. The most harmful constituent of saline soils is NaCl. Under saline conditions, $\mathrm{Na}^{+}$and $\mathrm{Cl}^{-}$ions increase in the plant and $\mathrm{K}^{+}$and $\mathrm{Mn}^{2+}$ decrease. To select salt tolerant rootstocks for citrus, screening of germplasm is required. Both in vivo and in vitro techniques have been used for screening. $\mathrm{NaCl}$ is the principal salt used for the screening experiments. The plants tolerate salinity either by exclusion or less transportation of $\mathrm{Na}^{+}$and $\mathrm{Cl}^{-}$to aerial plant parts. $\mathrm{Na}^{+}, \mathrm{Cl}^{-}$and $\mathrm{Na}: \mathrm{K}$ ratio are important chemical markers, which can be used for approximating the salt tolerance in citrus rootstocks. Callus browning can also be considered as an index for screening purposes. Cleopatra mandarin, Rangpur lime, Citrus macrophylla, Sunki mandarin and Shekwasha mandarin are rootstocks tolerant to salinity and rough lemon and trifoliate orange are sensitive. However, variation in salt tolerance exists among the strains of various citrus rootstocks.
\end{abstract}

Key words: salinity / salt tolerance / citrus rootstocks / screening / breeding / in vivo / in vitro

\section{INTRODUCTION}

Soil salinity is an immense problem for agricultural production. Vast areas of land in the world and in India have become unfit for cultivation owing to excessive salt concentrations in soils, mostly chlorides and sulfates of sodium, calcium and magnesium. Major inhibitory effects of salinity on plants include (i) osmotic inhibition of water availability and (ii) toxic effects of salt ions responsible for causing salt injury and nutrient imbalances. Although these are the common effects of salinity, they may depend upon weather conditions, water availability, plant species, type and concentration of ions and physiological stage of plant growth.

Citrus is grown in many semi-arid/tropical and subtropical climates where rainfall is limited, requiring irrigation for the plant growth. Soils in these areas are often saline, which affects the growth and yield of citrus crops. Citrus species are most sensitive to soil salinity (Maas, 1992), however, the capacity of citrus trees to tolerate salinity varies among different species and even among different strains within a species (Cooper et al. 1956; Furr et al. 1963; Furr and Ream, 1968; Newcomb 1978; Singh et al. 1997).

Salt tolerance of plants has been described as a quantitative trait, but its gene products are not well documented. For breeding programmes to develop plant salt tolerance, an understanding of salinity tolerance mechanisms is essential. Several efforts have been made to study and improve salt tolerance in plants.

Buffum (1896) first recognized the harmful nature of saline and alkali soils to plants. As early as in the year 1900, Loughridge observed that certain orange orchards in California, USA had suffered injury due to irrigating with saline water. Hilgard (1900) concluded that $\mathrm{NaCl}$ was the constituent of the irrigation water, which was responsible for the damage to those orange trees. Since then, a great deal of research work had been conducted in different countries on salinity tolerance and related aspects of citrus to various saline conditions. A review of the work done so far on the screening of citrus rootstocks for salt tolerance is presented below.

\section{EFFECT OF SALINITY ON CITRUS}

Effect of salinity on seed germination

Many researchers have studied salinity effects on seed germination of Citrus species. Caro et al. (1973) studied the effect of 
$\mathrm{NaCl}$ solution and reported that the germination was reduced with an increase in salinity. Mobayen \& Milthorpe (1978) stated that the seed germination of populations with slow germination was reduced even more by salt stress than those populations in which all the seeds germinated quickly.

The increased salt concentration significantly delayed and depressed seedling emergence initially and also reduced the seedling growth, but did not affect the subsequent seedling emergence (Zekri 1993c). The salinity affected seedling growth more than emergence, especially at high salinity levels. Shoot $\mathrm{Cl}^{-}$was more useful than total $\mathrm{Cl}^{-}$for evaluating the extent of salt stress and was a better parameter in ranking salt tolerance of the citrus rootstocks. Salt tolerance is not a constant characteristic in rootstocks, but varies with the stage of seedling development (Zekri, 1993c).

The effect of salt on seed imbibition and time of first seedling emergence was primarily related to osmosis, whereas, the effect on the final percentage of emergence and growth of seedlings was mainly related to toxicity (Zekri 1993a). Salinity generally delayed and reduced seedling emergence, reduced shoot and root biomass and altered the mineral composition of young seedlings, but the trend was not uniform among cultivars with different salt tolerance during emergence and that during seedling growth (Zekri 1993b, 1994). Salt tolerance at seedling emergence might not be a useful indicator for rapid screening of citrus cultivar's growth (Zekri 1993b, 1994). The percent of germinating seeds decreased and the number of days required for germination increased as the level of salinity increased, but these reductions and delays were rootstock specific (El-Desouky \& Atawia, 1998).

\section{Effect of salinity on plant growth and yield}

The major effects of salinity on plants are growth suspension, leaf injury symptoms and reduction in yield. Vegetative growth and fruit yield decrease in direct proportion to salt concentration in the soil. Chapman et al. (1969) reported that 30 and 60 meq/l salinity significantly reduced tree growth and fruiting of those, receiving high salt water were smaller in size. The rise in salinity was accompanied by a reduction in flushing frequency of the axillary buds and inhibition of flowering terminals, which will eventually reduce yields (Goell 1969).

Cooper and Peynado (1953) observed that salt treatment decreased growth of both young and old citrus trees. Peynado and Young (1969) stated that trees grew less and exhibited more salt injury under saline conditions. According to El-Kholi et al. (1979a), the growth of the trees was progressively reduced with increasing $\mathrm{Cl}^{-}$concentration. Dry weight of leaves, roots and stems were significantly reduced as compared with the controls. Further, Badawi et al. (1979) stated that salinity treatments resulted in lower leaf and root dry weight. El-Kholi et al. (1979b) reported that salinity severely reduced plant dry weight and pigment content.

Salinity reduced rind thickness and delayed maturation of fruit, but did not influence other fruit quality characteristics (Francois \& Clark, 1980). Growth of oranges budded on different rootstocks was depressed with increasing salinity (Joolka $e t$ al. 1980). Mobayen and Milthorpe (1980) observed greater differences between Cleopatra mandarin, trifoliate orange and Bakraie mandarin for leaf senescence and expansion rate under saline conditions and suggested that these criteria could be used for screening seedlings for salinity tolerance.

According to Cherif et al. (1981), growth of all parts of sour orange was severely limited by salinity, but symptoms of injury were expressed poorly. However, on Troyer citrange (Citrus sinensis x Poncirus trifoliata), necrosis was seen, but growth was less adversely affected by lower salinity levels and severely affected by the highest salinity level. Reduction in branch diameter under salinity was recorded by Dasberg et al. (1985), whereas, Duke et al. (1986) reported that shoot and root dry weight decreased with an increase in salinity.

Cerda et al. (1986) recorded that growth retardation and salt injury symptoms are rootstock dependent. The results of Attalla (1987) indicated that the dry weight of rootstocks decreased with an increase in salt concentration and the tolerant rootstocks had the lowest leaf: root ratio. Mean relative growth rate of young seedlings of $C$. aurantium did not depend on $\mathrm{NaCl}$ concentration, but the highest concentration of $\mathrm{NaCl}$ reduced leaf necrosis and leaf fall (Zid \& Grignon, 1986) and salinity treatment also decreased the growth of the main branches and root development (Bielorai et al., 1988). Dasberg et al. (1988a, b) reported that tree growth was retarded with high salinity irrigation water and main branch growth, observed in cross section, was also retarded.

Zekri and Parsons (1989) recorded a decrease in shoot: root ratio and an increase in root weight per unit length with an increase of $\mathrm{NaCl}$ concentration. A relationship was established between $\mathrm{NaCl}$ treatment and relative growth rate and it was concluded that reduction in relative growth rate caused by $\mathrm{NaCl}$ treatment was more scion cultivar dependent, whereas, defoliation was more rootstock dependent (Banuls et al. 1990). Zekri \& Parsons (1990a) concluded that sour orange 
seedlings, treated with nutrient solution containing various levels of $\mathrm{NaCl}$ alone or in combination with $\mathrm{CaSO}_{4}, \mathrm{CaCl}_{2}$ or $\mathrm{KCl}_{\text {, }}$ had reduced root and shoot dry weight.

Seedlings of sour orange with $\mathrm{NaCl}$ stress produced fewer roots and shallower root systems (Zekri and Parsons 1990b). Fibrous root weight/unit length increased. Growth was depressed and stomatal conductance was reduced. Plants had low root and shoot dry weights, fewer leaves and roots and were shorter, but they had an increased root density (Alva \& Syvertsen, 1991). At a relatively low salinity level, shoot and root dry weight, stem cross-sectional area, total leaf area and fibrous root length were reduced by 44-55 percent (Zekri 1991).

Garcia-Legaz et al. (1993) showed that shoot length of plants grafted on sour orange and Citrus volkameriana had greater reduction with increasing salinity than those grafted on Citrus macrophylla. Boman (1994) reported a reduction in canopy volume of about 7 percent for each $1.0 \mathrm{dS} / \mathrm{m}$ increase in irrigation water salinity over the base level of $0.7 \mathrm{dS} / \mathrm{m}$.

Salinity treatments greatly affected plant growth in terms of height, stem diameter and total plant fresh and dry weight in citrus rootstocks and these effects increased with increasing salinity, however Rangpur lime seedlings exhibited better growth (El-Hammady et al. 1995). Aljuburi (1996) also concluded that salinity influenced relative growth rates, stem diameter, stem and leaf dry weight, but the extent of the effects was rootstock dependent; some were tolerant and others were susceptible.

The $\mathrm{Cl}^{-}$salts markedly reduced plant growth in scion rootstock combinations, whereas, $\mathrm{NaNO}_{3}$ had very little effect (Banuls et al. 1997). Ruiz et al. (1997) reported that salt treatment significantly reduced both relative growth rate and net assimilation rate, whereas, leaf weight ratio showed no definite trend. Fernandez- Ballester et al. (1998) concluded that the degree of growth reduction from severe to mild from salinity depended upon which rootstock was used.

According to Garcia-Lidon et al. (1998), salinity reduced plant growth and the least affected rootstock was Citrus macrophylla. Nastou et al. (1999) reported that shoot growth decreased substantially at $\mathrm{NaCl}$ concentration above $15 \mathrm{mM}$. Growth response to different salt treatments was primarily determined by the osmotic effect, although in Citrus macrophylla, the ionic effect also seemed to be significant (Ruiz et al. 1999).

Howie \& Lloyd (1989) reported that trees irrigated with high salinity water have reduced flowering intensities and fruit set, slower fruit growth and late maturity of fruits. Kirkpatrick and Bitters (1969) suggested the use of the survival and threshold limits for new top growth and fibrous roots as a useful first approximation when selecting potentially salt tolerant citrus rootstocks.

Khanna \& Kumar (1990) reported that leaf area was reduced in trees after sixty days of irrigation with $\mathrm{NaCl}$ or $\mathrm{NaCl}+$ $\mathrm{Na}_{2} \mathrm{SO}_{4}$, but not with $\mathrm{Na}_{2} \mathrm{SO}_{4}$ alone. After 90 days, shoot growth and leaf number/shoot were reduced in treatments with $\mathrm{NaCl}$ or $\mathrm{NaCl}+\mathrm{Na}_{2} \mathrm{SO}_{4}$, whereas, $\mathrm{Na}_{2} \mathrm{SO}_{4}$ treated trees showed no significant changes. None of the treatments had a significant effect on stem diameter or tree height. Lloyd \& Howie (1989) recorded a reduction in leaf area and extensive abscission of leaves under salinity.

Shalhevet et al. (1974) reported a reduction in yield of a magnitude of $2.3 \mathrm{t} / \mathrm{ha}(2.3 \%)$ with per meq/l increase in $\mathrm{Cl}^{-}$for Shamouti orange on sweet lime and $3.25 \mathrm{t} / \mathrm{ha}$ (5.5\%) for Valencia orange on sour orange. Francois and Clark (1980) suggested that the yield reduction due to increasing salinity reflected a reduction in fruit number, not fruit size. The reduction in yield correlated with increased $\mathrm{Cl}^{-}$accumulation (Levy et al., 1992). Salinity negatively correlated with yield, but its effect was location specific (Cole and McCloud, 1985).

Reduction in yield with increasing salinity was also observed by Dasberg et al. (1985), Bielorai et al. (1988) and Nieves et al. (1992). Bielorai et al. (1988) reported that fruit quality was not impaired by salinity and the reduction in yield correlated with the number of fruits, not with the size of the fruit. A yield reduction of 9.0 percent was reported by Bielorai et al. (1983), when the crops were treated with high $\mathrm{Cl}^{-}$water. They further reported that total water uptake by the plants was reduced and that could be the reason for the yield reduction.

Washington Navel on sweet orange rootstock irrigated with $20 \mathrm{mM} \mathrm{NaCl} / \mathrm{m}^{3}$ had a greater number of vegetative flushes (at the expense of flowering), reproductive branches and mixed flushes reduced by salinity (Lloyd \& Howie, 1989). Maas (1992) concluded that soil salinity significantly limits the citrus production worldwide with grapefruit, lemons and oranges being the most susceptible. Fruit yields decreased by 13 percent for each $1.0 \mathrm{dS} / \mathrm{m}$ increase in electrical conductivity of saturated soil extract once the salinity exceeds a threshold limit of $1.4 \mathrm{dS} / \mathrm{m}$.

\section{Salinity tolerance limit}

A salt content of 0.05 percent in water is considered to be the upper limit for orange groves irrigated with saline water (de 
Boxio, 1963). Salt concentration more than 0.11 per cent in water was highly detrimental to orange plant growth (Bhambota \& Kanwar, 1970).

\section{Effect of salinity on chemical composition of plant}

The salinity affected the plant composition in terms of different chemical constituents. Chapman et al. (1969) reported that tentative injury at threshold levels in four-month-old spring cycle leaves were 0.30 per cent $\mathrm{Cl}^{-}$(dry matter) in leaves from non-fruiting terminals and 0.50 per cent in leaves from fruiting terminals. $\mathrm{Cl}^{-}$accumulated in leaves progressively with age. The effect of $\mathrm{Cl}^{-}$ions in the citrus leaves was a reduction in leaf longevity due to increased chlorosis, earlier senescence and abscission (Goell, 1969). Among the trees of Eureka lemon on five rootstocks, rough lemon, Eremocitrus, Rangpur lime, sour orange and Cleopatra mandarin, trees on rough lemon had the highest leaf $\mathrm{Cl}^{-}$content, leaf drop rate and a high degree of chlorosis, but the crown volume was greater in this rootstock. This type of tolerance is described as a specific rootstock effect (Goell, 1969).

Salerno (1975) reported that salt affected leaves contained abnormally high levels of $\mathrm{Cl}^{-}$. According to Guillen et al. (1978), an increase in salinity depressed leaf $\mathrm{K}^{+}$and $\mathrm{Mn}^{2+}$ contents and increased $\mathrm{N}$ and $\mathrm{Mg}^{2+}$, but $\mathrm{P}, \mathrm{Ca}^{2+}$ and $\mathrm{Fe}^{2+}$ contents were unaffected and the effect on ion content was rootstock specific. However, Abdel-Messih et al. (1979) recorded that salinity increased $\mathrm{Na}^{+}, \mathrm{Ca}^{2+}$ and $\mathrm{K}^{+}$levels in leaves of Cleopatra mandarin, sour orange, $\mathrm{F}_{1}$ hybrids, poor-man orange and rough lemon, whereas, leaf $\mathrm{Mg}^{2+}, \mathrm{N}$ and $\mathrm{Fe}^{2+}$ levels fell and $\mathrm{P}$ was unaffected. They further noticed rootstock specificity in accumulation of individual ions.

Badawi et al. (1979) recorded an increase in $\mathrm{Cl}^{-}$and $\mathrm{Na}^{+}$in plants treated with $\mathrm{NaCl}$, but the $\mathrm{Fe}^{2+}, \mathrm{Mn}^{2+}$ and $\mathrm{B}$ concentrations remained constant. Mobayen \& Milthorpe (1980) stated that $\mathrm{Na}^{+}$concentration in leaves is linearly related to concentration in the external solution and increases with time. $\mathrm{Na}^{+}, \mathrm{P}, \mathrm{Ca}^{2+}$ and $\mathrm{Mg}^{2+}$ concentrations were higher in Bakraie mandarin than in Cleopatra mandarin. Grieve (1983) reported that the most salt tolerant rootstocks were Rangpur lime, Cleopatra mandarin, Carrizo and Troyer citranges and the least tolerant was Poncirus trifoliata.

Grieve \& Walker (1983) reported that plants differed in their leaf $\mathrm{Cl}^{-}$and $\mathrm{Na}^{+}$concentrations, but there was little or no difference between root $\mathrm{Cl}^{-}$and $\mathrm{Na}^{+}$concentrations. The different accumulation patterns of $\mathrm{Cl}^{-}$and $\mathrm{Na}^{+}$in different species were consistent with the existence of apparently separate mechanisms. Cleopatra mandarin, Rangpur lime, Citrus macrophylla and Appleby Smooth Seville accumulated significantly less $\mathrm{Cl}^{-}$than Poncirus trifoliata and rough lemon.

Walker \& Douglas (1983) reported differences between rootstocks in leaf $\mathrm{Cl}^{-}$concentration and to a lesser extent in shoots, emphasizing marked differences in root to shoot $\mathrm{Cl}^{-}$transport. Root, stem and leaf $\mathrm{Na}^{+}$concentrations increased with an increase in salt concentration, but a reduction in $\mathrm{K}^{+}$occurred in stems and roots only. Walker et al. (1983) concluded that Rangpur lime and Cleopatra mandarin restricted uptake and transport of $\mathrm{Cl}^{-}$to shoots and leaf $\mathrm{K}^{+}$concentrations remained similar to those of plants not treated with salt (controls), indicating that $\mathrm{K}^{+}$is not replaced with toxic ions in the leaves of tolerant rootstocks. According to Behboudian et al. (1986), scions grafted on Cleopatra mandarin accumulate less $\mathrm{Cl}^{-}$in their leaves and stems than Valencia orange on rough lemon and rough lemon seedlings, demonstrating that $\mathrm{Cl}^{-}$accumulation in shoots is rootstock dependent, but $\mathrm{Na}^{+}$accumulation in shoots is more scion dependent. They observed that salinity caused a decrease in $\mathrm{K}^{+}$concentration in all roots and shoots.

Walker (1986) reported that trifoliate orange treated at lower salinity levels possessed the ability to restrict $\mathrm{Na}^{+}$ accumulation in leaves, but not at higher salinity. Salt tolerant Cleopatra mandarin plants tended to show a marginal increase in leaf Na:K ratio. There was a marked reduction in root to leaf $\mathrm{Na}^{+}$transport.

Zid \& Grignon (1986) reported that $\mathrm{NaCl}$ had no effect on $\mathrm{K}^{+}$and $\mathrm{N}$, however it did lead to large $\mathrm{Na}^{+}$and $\mathrm{Cl}^{-}$ accumulation in leaves increasing with increasing medium concentration. According to Syvertsen et al. (1988), an increase in the concentration of $\mathrm{Cl}^{-}$in trees on trifoliate orange rootstock was significantly higher than those on sweet orange rootstock. $\mathrm{Na}^{+}$and $\mathrm{Cl}^{-}$in foliage increased and $\mathrm{K}^{+}$decreased with the age of the leaves, especially when irrigated with saline water.

Banuls et al. (1990) reported that scions grafted on Cleopatra mandarin accumulated less $\mathrm{Cl}^{-}$in leaves than those grafted on Troyer citrange. The distribution of $\mathrm{Cl}^{-}$in the whole plant showed that Cleopatra mandarin had a reduced ability to transport $\mathrm{Cl}^{-}$from roots to leaves. However, $\mathrm{Na}^{+}$content was lower in Troyer citrange than in Cleopatra mandarin, indicating that Troyer citrange restricted $\mathrm{Na}^{+}$transport to scion cultivar. Salinity decreased $\mathrm{K}^{+}, \mathrm{Ca}^{2+}$ and $\mathrm{Mg}^{2+}$ concentrations in leaves and roots (Banuls et al., 1990). Leaf nutrient contents and responses to salinity were rootstock dependent, as trees on sour orange rootstock had higher $\mathrm{K}^{+}$and $\mathrm{Ca}^{2+}$, but lower $\mathrm{Mg}^{2+}$ and $\mathrm{Cl}^{-}$than leaves on Carrizo citrange (Alva \& Syvertsen, 1991). Leaf $\mathrm{K}^{+}$of trees on Carrizo citrange and leaf $\mathrm{Mg}^{2+}$ of trees on sour orange were reduced by salinity. 
Susceptibility of sour orange rootstock to salt stress was observed due to its failure to exclude $\mathrm{Cl}^{-}$, even at low salt levels (Zekri 1991). However, Nieves et al. (1992) were of the opinion that $\mathrm{Cl}^{-}$accumulation was primarily dependent on scion. This view was also supported by Garcia-Legaz et al. (1993).

According to Walker et al. (1993), both $\mathrm{Cl}^{-}$and $\mathrm{Na}^{+}$could reduce assimilation rates in salt stressed lemon leaves. An increase in leaf $\mathrm{Na}^{+}$and $\mathrm{Cl}^{-}$accounted for a 54-96 percent reduction in the osmotic potential in the leaves of trees irrigated with water containing $\mathrm{NaCl}$, whereas, an increase in $\mathrm{Na}^{+}$and $\mathrm{SO}_{4}{ }^{2-}$ accounted for a 33-71 percent reduction in the osmotic potential in the leaves of trees irrigated with water containing $\mathrm{Na}_{2} \mathrm{SO}_{4}$.

Boman (1994) concluded that trees showed excessive foliar $\mathrm{Na}^{+}$or $\mathrm{Cl}^{-}$accumulation at the highest salinity level. Trees grafted on Cleopatra mandarin were able to exclude $\mathrm{Cl}^{-}$better than trees grafted on other rootstocks. Carrizo citrange trees accumulated high levels of $\mathrm{Cl}^{-}$, but they were effective in excluding $\mathrm{Na}^{+}$. Further, Garcia-Legaz et al. (1994) reported that scion cultivars grafted on Citrus macrophylla had lower $\mathrm{Na}^{+}$and $\mathrm{Cl}^{-}$concentrations in their leaves, but higher root concentrations than grafted on other rootstocks, indicating less transportation of these ions from roots to the aerial parts.

According to Banuls \& Primo-Millo (1995), scions grafted on Cleopatra mandarin accumulated less $\mathrm{Cl}^{-}$in their leaves than did scions grafted on Troyer citrange. Also, leaf $\mathrm{Cl}^{-}$concentration in Clementine scions was lower than in Navel orange, when both were grafted on the same rootstock. However, $\mathrm{Na}^{+}$concentration was lower in scions grafted on Cleopatra mandarin than scions grafted on Troyer citrange. This clearly indicates the specificity of scion and rootstock combinations, suggesting that the accumulation of these ions is not merely dependent on rootstock or scion cultivar.

El-Hammady et al. (1995) reported that irrigation with saline water increased leaf $\mathrm{Mg}^{2+}, \mathrm{Na}^{+}$and $\mathrm{Cl}^{-}$regardless of rootstock, while irrigation with tap water increased $\mathrm{Ca}^{2+}$. Volkamer lemon seedlings contained higher leaf $\mathrm{Mg}^{2+}$ concentrations and lower amounts of $\mathrm{Na}^{+}$and $\mathrm{Cl}^{-}$, indicating that such rootstocks could tolerate salinity. Sour orange accumulated higher leaf $\mathrm{Na}^{+}$and $\mathrm{Cl}^{-}$and therefore, is considered to be susceptible to salinity. Hence, susceptibility or tolerance to salinity is dependent on the translocation of $\mathrm{Na}^{+}$and $\mathrm{Cl}^{-}$ions from roots to the aerial parts of the plant.

According to Banuls et al. (1997), relatively more $\mathrm{Cl}^{-}$accumulated in the leaves and less in the roots of Poncirus trifoliata than in Cleopatra mandarin, but the concentration of $\mathrm{Na}^{+}$was higher in Cleopatra mandarin than in Poncirus trifoliata. They concluded that salinity, by providing an external $\mathrm{Cl}^{-}$supply, induces growth and gas exchange changes. Ruiz et al. (1997) added that, in addition to the osmotic and the inhibitory effects of high $\mathrm{Cl}^{-}$and $\mathrm{Na}^{+}$concentrations, salinity causes an imbalance of essential nutrients. In a significant report, Garcia-Lidon et al. (1998) concluded that none of the rootstocks were able to exclude $\mathrm{Cl}^{-}$and $\mathrm{Na}^{+}$from scion leaves and salinity and rootstock/scion combinations influenced macro and micronutrient concentrations. Nastou et al. (1999) reported that $\mathrm{Cl}^{-}$accumulation increased with increasing $\mathrm{NaCl}$ concentration in nutrient solution while, $\mathrm{Na}^{+}$accumulation increased markedly at higher concentrations of $\mathrm{NaCl}$.

Storey \& Walker (1999) reported that salt damage in citrus was associated with accumulation of $\mathrm{Na}^{+}$and $/ \mathrm{or} \mathrm{Cl}^{-}$in leaf cells. Greater salt resistance of rootstocks, such as that of Rangpur lime and Cleopatra mandarin are related to their capacity to limit leaf $\mathrm{Cl}^{-}$accumulation. Rootstocks, like trifoliate orange, have the capacity to restrict $\mathrm{Na}^{+}$transport to the shoots at low salinity. Storey \& Walker (1999) further reported that the traits which restrict the root to shoot transport of $\mathrm{Cl}^{-}$and $\mathrm{Na}^{+}$ in citrus are heritable. The regulation of leaf $\mathrm{Cl}^{-}$concentration in citrus appeared to be primarily associated with the transport process in roots, e.g. root uptake and unloading of $\mathrm{Cl}^{-}$at the root symplast/xylem interface. The capacity of rootstocks, such as trifoliate orange, to limit $\mathrm{Na}^{+}$accumulation in leaves was associated with reabsorption $\mathrm{of}^{+}$from the xylem stream in the root and basal stem.

\section{RELATIVE SALT TOLERANCE OF CITRUS SPECIES}

Salt tolerance of woody plants, particularly of fruit trees, was found to be relatively high during early years when vegetative growth was dominant and it declined with the advent of fruiting (Devjatov, 1961). According to Bahodyrov (1956), salinity retarded seed germination and early growth, after which trees became resistant, whereas, Beeftink (1955) observed that tree age had no clear effect on sensitivity to salinity.

Relative tolerance of citrus cultivars and species have been studied by various researchers (Cooper et al. 1951a, b; Cooper 1961, 1962; Bhambota \& Kanwar 1968, 1969; Abbadi 1969; Singh et al. 1997). Among the citrus and related species, Cleopatra mandarin, Severinia buxifolia and Rangpur lime were the most tolerant rootstocks (Cooper 1961, 1962; Singh et al. 1997) and sour orange, rough lemon, sweet lemon and Cambodian sweet lime were moderately tolerant (Cooper et al. 1951a, b). Holevas \& Demetrisdes (1963) found that sweet oranges were least affected, citron and lemons, slightly sensitive, 
whereas, sour orange and mandarin were observed to have moderate salinity tolerance. Bhambota \& Kanwar (1968, 1969) reported that Karna Khatta, Galgal (Citrus limon), trifoliate orange and rough lemon were progressively less tolerant to salinity. When budded on rough lemon, Hamlin was the most tolerant, followed by Valencia Late, Pineapple and Blood Red sweet oranges. A comprehensive list of the relative salt tolerances of citrus rootstocks is presented in Table

Table 1. Relative salinity tolerance of citrus and related species.

\begin{tabular}{|c|c|c|c|c|}
\hline Citrus spp. & Tolerant & $\begin{array}{l}\text { Moderately } \\
\text { tolerant }\end{array}$ & Susceptible & Reference \\
\hline \multirow[t]{3}{*}{$\begin{array}{l}\text { Cleopatra } \\
\text { mandarin }\end{array}$} & Yes & - & - & $\begin{array}{l}\text { Furr \& Ream, 1968; Joolka \& Singh 1979; Grieve 1983; } \\
\text { Grieve and Walker 1983; Walker et al. 1983; Behboudian } \\
\text { et al.1986; Cerda et al. 1986; Zekri 1991; Banuls \& Primo- } \\
\text { Millo 1995; Banuls et al. 1997; Singh et al. 1997; Storey } \\
\text { \& Walker, 1999. }\end{array}$ \\
\hline & - & Yes & - & Mobayen \& Milthorpe 1980; El-Hammady et al. 1995. \\
\hline & - & - & Yes & Joolka et al. 1980. \\
\hline \multirow[t]{2}{*}{ Rangpur lime } & Yes & - & - & $\begin{array}{l}\text { Furr \& Ream 1968; Joolka and Singh 1979; Grieve 1983; } \\
\text { Grieve \& Walker 1983; Walker et al. 1983; Walker \& } \\
\text { Douglas 1983; El-Hammady et al. 1995; Storey \& Walker } \\
\text { 1999. }\end{array}$ \\
\hline & - & - & Yes & Joolka et al. 1980. \\
\hline \multirow[t]{2}{*}{ Rough lemon } & Yes & - & - & Joolka et al. 1980 \\
\hline & - & - & Yes & $\begin{array}{l}\text { Joolka \& Singh 1979; Grieve \& Walker 1983; } \\
\text { Behboudian et al. 1986; Singh et al. } 1997 .\end{array}$ \\
\hline Trifoliate orange & - & - & Yes & $\begin{array}{l}\text { Mobayen and Milthorpe 1980; Grieve, 1983; Grieve \& } \\
\text { Walker 1983; Walker 1986; Syvertsen } \text { et al. } 1988 \text {; Banuls } \\
\text { et al. 1997; Singh et al. 1997; Storey and Walker 1999. }\end{array}$ \\
\hline \multirow[t]{2}{*}{ C. macrophylla } & Yes & - & - & $\begin{array}{l}\text { Grieve \& Walker 1983; Garcia-Legaz et al. 1993; 1994; } \\
\text { Garcia-Lidon et al. } 1998 .\end{array}$ \\
\hline & - & - & Yes & $\begin{array}{l}\text { Cerda et al. 1986; Fernandez-Ballester et al. 1998; Ruiz et } \\
\text { al. } 1999 .\end{array}$ \\
\hline Sour orange & - & - & Yes & $\begin{array}{l}\text { Cherif et al. 1981; Cerda et al. 1986; Zekri \& Parsons } \\
\text { 1990b; Zekri 1991; Garcia-Legaz et al. 1993, 1994; El- } \\
\text { Hammady et al. 1995; Fernandez-Ballester et al. 1998. }\end{array}$ \\
\hline \multirow[t]{2}{*}{ Troyer citrange } & Yes & - & - & Cherif et al. 1981; Grieve 1983. \\
\hline & - & - & Yes & $\begin{array}{l}\text { Joolka et al. 1980; Banuls et al. 1990; Banuls \& Primo- } \\
\text { Millo } 1995 .\end{array}$ \\
\hline \multirow[t]{2}{*}{ C. volkameriana } & Yes & - & - & El-Hammady et al. 1995. \\
\hline & - & Yes & - & Garcia-Legaz et al. 1993, 1994; El-Hammady et al. 1995. \\
\hline Kharna Khatta & - & - & Yes & Walker \& Douglas 1983. \\
\hline Sunki mandarin & Yes & - & - & Furr \& Ream 1968. \\
\hline Shekwasha mandarin & Yes & - & - & Furr \& Ream 1968. \\
\hline Carrizo citrange & Yes & - & - & Grieve 1983. \\
\hline Bakraie & Yes & - & - & Mobayen \& Milthorpe 1980 \\
\hline
\end{tabular}

\section{BREEDING AND SCREENING OF CITRUS ROOTSTOCKS FOR SALT TOLERANCE}

Different techniques for screening citrus rootstocks for salt tolerance have been used by different researchers. Some used in vivo techniques and others used in vitro techniques. Amongst the in vivo techniques, germinating seeds in saline soil, irrigating seeds with saline water under artificial conditions and screening seedlings in salinized plots/pots were common. Some scientists used cuttings for screening purposes. Both types of conditions, soil salinity and irrigation with saline water have been used in the majority of the screening programmes. $\mathrm{NaCl}$ has been used as the principal salt for screening for salt tolerance. Experiment durations varied from 6 weeks of salt stress in laboratory experiments to several years in field 
evaluations.

In vitro screening techniques have not been used in citrus for screening against salt tolerance, but they have been used for the selection of salt tolerant cell lines. In citrus, the techniques of callus induction and plant regeneration have been well documented, but there may be differences for different species and sources of explants.

\section{In vivo screening and breeding for salt tolerance}

Considerable genetic variability in salt uptake and tolerance has been noted for citrus, especially between rootstocks. For rootstock screening for salt tolerance, seed germination is the primary technique.

\section{Seed germination under saline conditions}

Caro et al. (1973) immersed seeds of Troyer citrange, bitter orange, Citrus macrophylla and Kinnow mandarin (King mandarin x Willowleaf mandarin) for 12 hours in a $\mathrm{NaCl}$ solution of four concentrations between 0 and $2.4 \mathrm{~g} / \mathrm{l}$. They recorded that all rootstocks showed a similar trend in germination as the salinity levels increased. Mobayen \& Milthorpe (1980) studied the germination behaviour of Poncirus trifoliata, Cleopatra mandarin and Bakraie mandarin seeds in solutions of $\mathrm{NaCl}$ or $\mathrm{Na}_{2} \mathrm{SO}_{4}$ at $0,-250,-500$ or $-750 \mathrm{~J} / \mathrm{kg}$ water potential and reported that seed germination of populations with typically slow germination was slowed much more by salt stress than that of populations in which all the seeds typically germinate quickly.

Zekri (1993c) sowed the seeds of three citrus rootstocks, Cleopatra mandarin, sour orange and trifoliate orange, in a green house and irrigated them with water having different salt concentrations (5,10,20,40 and $80 \mathrm{mmol} / \mathrm{l})$ by adding $\mathrm{NaCl}$ and $\mathrm{CaSO}_{4}$ in a ratio of 4:1 to Hoagland's Solution. He concluded that salt tolerance was not a constant characteristic in rootstocks, but varied with the stage of seedling development. In another experiment by Zekri (1993a), dry or water imbibed seeds of Cleopatra mandarin, sour orange and Poncirus trifoliata were sown in trays containing seed compost covered with vermiculite and irrigated with water having no salt (control) or $50 \mathrm{mM} \mathrm{NaCl}$ or mannitol at $17 \mathrm{~g} / \mathrm{l}$ or PEG at $130 \mathrm{~g} / \mathrm{l}$. He concluded that the effect of salts on seed imbibition and time to emergence of first seedlings was primarily osmotic, whereas, the effect on the final percentage of emergence and seedling growth was mainly a toxic one.

Zekri (1993b) used cellular trays containing a commercial growing medium covered with vermiculite for seed germination of sour orange, Citrus volkameriana, Ridge Pineapple, Cleopatra mandarin, Carrizo and Troyer citranges, Swingle citrumelo and rough lemon. The seeds were irrigated with 10 percent Hoagland's Solution containing 50 or 100 $\mathrm{mmol} \mathrm{NaCl} / \mathrm{m}^{3}+50 \mathrm{mmol} \mathrm{CaSO} / \mathrm{m}^{3}$. Zekri observed no uniform trend among cultivars between salt tolerance during emergence and that during seedling growth.

In a green house study, seeds were sown in trays by Zekri (1994) and irrigated with four salinity levels; control (100 ppm NaCl), 3000 ppm NaCl, 6000 ppm NaCl and 3000 ppm NaCl +3500 ppm $\mathrm{CaSO}_{4}$. The addition of $\mathrm{CaSO}_{4}$ enhanced the emergence of the first seedling, final percentage of emergence and seedling growth. He suggested that salt tolerance at seedling emergence might not be a useful indicator for rapid screening of citrus cultivars.

\section{Breeding/selection for salt tolerance at whole plant level}

Furr \& Ream (1968) reported that when a highly salt-tolerant variety, such as Rangpur lime, was crossed with one of low tolerance, such as Rubidoux trifoliate orange, the hybrid progeny exhibited varying degrees of salt tolerance, indicating the heritable nature of salt tolerance in citrus. Furthermore, they used $\mathrm{Cl}^{-}$tolerant varieties such as Cleopatra mandarin, Rangpur lime, Sunki mandarin and Shekwasha mandarin for breeding salt tolerant rootstocks. They concluded that inheritance of salt tolerance is a quantitative trait and they produced some $\mathrm{F}_{1}$ seedlings which were as tolerant to salinity as Cleopatra mandarin.

Bhambota \& Kanwar $(1968,1969)$ conducted experiments in sandy loam soil with a total salt concentration of about 1900 ppm and reported that Karna Khatta, Galgal, trifoliate orange and rough lemon were progressively less tolerant to salinity when used as rootstocks for Blood Red sweet orange. Swingle citrumelo was reported to be moderately tolerant to salinity (Hutchinson 1974).

Ream \& Furr (1976) screened hybrids having one Cleopatra mandarin or Rangpur lime parent along with sour orange and reported that 20 of the hybrids were as tolerant to salinity as the tolerant parents. Patil \& Bhambota (1978) studied the behaviour of six citrus rootstocks grown at salinity levels of $2-8 \mathrm{mmhos} / \mathrm{cm}$ in pots and reported that Cleopatra mandarin, Jatti Khatti and Jullandhari Khatti were the most tolerant rootstocks based on percent seedling mortality, stem and root growth and leaf number. 
Rokba et al. (1979) used saline irrigation water $\left(\mathrm{NaCl}+\mathrm{CaCl}_{2}\right)$ and screened the citrus rootstocks and hybrids. Cleopatra mandarin proved to be the most salt tolerant rootstock. Mobayen and Milthorpe (1980) grew seedlings of three rootstocks in sand and subjected them to $\mathrm{NaCl}$ concentrations ranging from 2.6 to $152.6 \mathrm{~mol} / \mathrm{m}^{3}$ in basic nutrient solution for 4 or 6 weeks. Bakraie mandarin, followed by Cleopatra mandarin, was reported as salt tolerant. Furthermore, they suggested that leaf abscission and expansion rates may provide useful indices for screening seedlings for salinity tolerance and that leaf analysis is less satisfactory.

When seedlings of Citrus reticulata and Citrus grandis were grown at $\mathrm{NaCl}$ concentrations of 0, 200, 300, 400, 500, 1200 or 2000 ppm, seedlings of Citrus grandis were shown to be more tolerant to high $\mathrm{NaCl}$ concentrations (Harahap 1984). Syvertsen et al. (1988) used mature Valencia orange trees grafted on Poncirus trifoliata or sweet orange and irrigated them with river water or river water $+\mathrm{NaCl}$. They reported the specific effects of rootstocks/scions on ion accumulation and growth of the trees under salinity. The specific effects were; an increase in $\mathrm{Cl}^{-}$concentration in trees grafted on trifoliate orange was significantly higher than those grafted on sweet orange, $\mathrm{Na}^{+}$and $\mathrm{Cl}^{-}$concentrations increased in foliage and $\mathrm{K}^{+}$ concentration decreased with leaf age.

Gallasch \& Dalton (1989) conducted an experiment in a shade house, using highly saline irrigation water $(8700 \mathrm{uS} / \mathrm{cm}$ conductivity) and screened 28 imported rootstocks, along with three rootstocks widely used in Australia. Fifteen of the imported rootstocks showed no significant reduction in plant growth after 84 days of salt treatment and were, therefore, considered to be highly salt tolerant. The response of five citrus rootstocks to soil salinity was investigated in greenhouse studies by Hassan \& Galal (1989). When seedlings were six-month-old, a salt treatment was applied. The salt solution consisted of $\mathrm{Ca}, \mathrm{Mg}, \mathrm{Na}, \mathrm{K}, \mathrm{CO}_{3}, \mathrm{HCO}_{3}, \mathrm{Cl}$ and $\mathrm{SO}_{4}$. Rangpur lime was recorded as the most tolerant rootstock to salinity.

When seedlings of Cleopatra mandarin, sour orange, rough lemon and Troyer citrange, grown in pots in a green house were supplied with nutrient solutions containing $\mathrm{NaCl}, \mathrm{KCl}$ or $\mathrm{CaCl}_{2}$ at 20 or $40 \mathrm{meq} / \mathrm{l}$, seedling growth was progressively affected by all salt levels. $\mathrm{NaCl}$ had the most adverse effect, followed by $\mathrm{KCl}$ and $\mathrm{CaCl}_{2}$. Cleopatra mandarin was the least affected and rough lemon and Troyer citrange were the most affected, whereas sour orange was moderately affected (Salem and El-Khorieby, 1989).

According to Chen et al. (1990), salt damage to citrus plants is due to high concentrations of $\mathrm{Cl}^{-}, \mathrm{Na}^{+}$or $\mathrm{HCO}_{3}^{-}$in the soil and it is possible to solve the problem of salt damage by using salt tolerant rootstocks, since the absorption and accumulation of $\mathrm{Cl}^{-}$and $\mathrm{Na}^{+}$are controlled by rootstocks. Furthermore, they stated that salt tolerance is a heritable quantitative characteristic in citrus, so, it is of great importance to identify and screen the salt tolerant germplasm, which can be used directly as rootstocks or as breeding materials.

Nieves et al. (1991) grew one-year-old plants of Verna and Fino lemon cultivars, budded onto sour orange or Alemow, in nutrient solutions containing 2 (control), 40 or $80 \mathrm{mmol} \mathrm{NaCl} / \mathrm{m}^{3}$ for 75 days. Growth of all the combinations was affected by the increase in salinity, but the effect was more severe on Alemow. They concluded that differences in the parameters determined in response to salinity were attributable to the differential capacity of each specific rootstock/scion combination to import $\mathrm{Cl}^{-}$and $\mathrm{Na}^{+}$to leaves.

Sykes (1992) reported on the selection of new salt-excluding citrus hybrids, which performed better than their parents when grafted with a common scion and grown in artificially salinized field plots. Lea-Cox \& Syvertsen (1993) grew fivemonth-old Cleopatra mandarin and Citrus volkameriana seedlings in pots of fine sand and irrigated with either non-saline $($ Ece $=0.23 \mathrm{dS} / \mathrm{m})$ or saline $($ Ece $=6.13 \mathrm{dS} / \mathrm{m})$ water by using a 3:1 $\mathrm{NaCl}: \mathrm{CaCl}_{2}$ solution over a four-week-period. Citrus volkameriana was reported to be more tolerant to salinity than Cleopatra mandarin.

Singh et al. (1997) screened six-month-old seedlings of 20 rootstocks in a pot experiment with four levels of $\mathrm{Cl}^{-}$in irrigation water, control, 300, 600 and $900 \mathrm{ppm} \mathrm{Cl}^{-}$through $\mathrm{NaCl}$, applied for up to two months and reported that variability among strains within a rootstock exists. Khanna \& Kumar (1990) grew two-year-old plants of Nagpur mandarin budded on rough lemon in pots. The pots contained salinized soil from control ( $0.3 \mathrm{mmhos} / \mathrm{cm}), \mathrm{NaCl}$ at 3,6 and $9 \mathrm{mmhos} / \mathrm{cm}, \mathrm{Na}_{2} \mathrm{SO}_{4}$ at 3, 6 and $9 \mathrm{mmhos} / \mathrm{cm}$ and $\mathrm{NaCl}+\mathrm{Na}_{2} \mathrm{SO}_{4}$ at 3, 6 and 9 mmhos/cm. They reported that $\mathrm{NaCl}$ was more harmful than $\mathrm{Na}_{2} \mathrm{SO}_{4}$.

In a pot experiment, seedlings of four rootstocks, Cleopatra mandarin, rough lemon, Rangpur lime and trifoliate orange were irrigated with 0 (control), 300, 600, 900 or $1200 \mathrm{ppm} \mathrm{Cl}^{-}$as $\mathrm{NaCl}$ for 75 days, and it was reported that trifoliate orange was the most tolerant rootstock to salinity (Srivastava et al. 1998). Levy et al. (1999) studied the effect of irrigation with saline water on six citrus genotypes in a short-term field experiment using salinity levels ranging from 2.0 to $6.4 \mathrm{dS} / \mathrm{m}$. Cleopatra mandarin was observed to be the best $\mathrm{Cl}^{-}$excluder. Singh (2000) reported that Rangpur lime was tolerant to salinity due to its low seedling mortality, low concentrations of $\mathrm{Na}^{+}$and $\mathrm{Cl}^{-}$and maintenance of a low Na: $\mathrm{K}$ ratio in aerial 
parts (leaves + stem) of the seedlings.

\section{In vitro selection and breeding for salt tolerance}

Kochba \& Spiegel-Roy (1980) selected ovular callus lines of Shamouti orange, which had an increased tolerance to $\mathrm{NaCl}$ after being treated with gamma rays $(8-16 \mathrm{kr})$. The selected lines had a more rapid growth rate and were stable after the removal of selection pressure. Embryoids were developed from the selected callus lines. Furthermore, Ben-Hayyim \& Kochba (1982) reported that the selected lines were able to grow in the presence of $0.2 \mathrm{M} \mathrm{NaCl}$. They observed that the growth curve of the selected salt tolerant lines in presence of $\mathrm{NaCl}$ showed a longer lag period, slightly slower rate of increase in fresh weight and about a 50 percent yield decrease as compared with the same line in the absence of salt.

According to Kochba et al. (1982), the increased salt tolerance of callus lines of Shamouti and sour orange was retained even after three consecutive transfers to a medium without salt. The NaCl-tolerant selected lines also grew well on media containing $\mathrm{Na}_{2} \mathrm{SO}_{4}$ or $\mathrm{K}_{2} \mathrm{SO}_{4}$, but poorly on a medium containing $\mathrm{KCl}$. They further reported that embryoids regenerated from salt tolerant callus survived and grew better in saline media than embryoids regenerated from the original salt sensitive callus. Further, Ben-Hayyim and Kochba (1983) determined that the $\mathrm{NaCl}$ tolerant ovular callus line of Shamouti orange proved to be a true cell line variant.

Matsumoto \& Yamaguchi (1984) studied on the development of seven salt tolerant lines from EMS treated material and found that the lines with the highest salt tolerance were derived from the material which had undergone the highest exposure to EMS. Ben-Hayyim et al. (1985) compared the selected NaCl-tolerant cell lines with non-selected lines with respect to their growth and internal ion content. All the selected lines took up similar or even larger amounts of $\mathrm{Na}^{+}$and $\mathrm{Cl}^{-}$ than the $\mathrm{NaCl}$-sensitive cell lines, but the selected lines maintained higher growth rates and $\mathrm{K}^{+}$concentrations than the nonselected lines, when grown under similar $\mathrm{NaCl}$ concentrations. Spiegel-Roy \& Ben-Hayyim (1985) also attempted to select for salt tolerance to $\mathrm{NaCl}$ in Citrus sinensis and Citrus aurantium. They selected tolerant cells in media containing up to 0.17 $\mathrm{M} \mathrm{NaCl}$. Embryoids from a selected line of Citrus sinensis showed greater tolerance to $\mathrm{NaCl}$ in medium than comparable embryoids of an unselected line. Furthermore, they compared plantlets from one tolerant line with plantlets from unselected controls and found that the selected lines had a greater adaptation to salt $(0.085 \mathrm{M}$ to $0.12 \mathrm{M}$ of $\mathrm{NaCl})$ and less leaf burn symptoms.

Ben-Hayyim \& Goffer (1989) attempted plant regeneration from a NaCl-selected salt tolerant callus culture of Shamouti orange and concluded that $\mathrm{NaCl}$ interfered with the regeneration process, specifically embryogenesis and/or embryo development into plantlets. $\mathrm{NaCl}$ presence during callus growth probably changed the balance of phytohormones, which are later manifested in plant regeneration. They further reported that the citrus salt tolerant callus yielded salt tolerant embryos and salt tolerant calli derived from regenerated plantlets, which indicates that salt tolerance is acquired at the whole plant level.

Deng et al. (1989) developed ovular callus in the medium and protoplasts were isolated and irradiated with various mutagens and, as in the Ben-Hayyim and Goffer (1989) experiment, calli were induced and NaCl-tolerant cell lines were selected after 6-7 passages of irradiated callus in a medium containing 0.8 percent $\mathrm{NaCl}$ and then plantlets were regenerated. They further observed that selected mutants exhibited higher proline accumulation, lower peroxidase activity and altered $\mathrm{Na}^{+}$and $\mathrm{Cl}^{-}$absorption as compared to original callus lines.

Two models were obtained by computer aided fitting of the base-survival curves of cultured cells after exposure to gamma rays and EMS by Deng et al. (1990). They selected $\mathrm{NaCl}$ tolerant lines of Jincheng and Taoyecheng oranges by subjecting their nucellar calli to gamma rays and EMS followed by 10 passages of selection in vitro. The selected lines were reported to be salt tolerant. They accumulated more proline, maintained a higher level of $\mathrm{K}^{+}$and absorbed less $\mathrm{Cl}^{-}$and $\mathrm{Na}^{+}$ than the original calli. Protoplasts were isolated from the selected calli and they were developed into embryoids, which were later germinated into plantlets.

Piqueras \& Hellin (1992) selected Citrus limonum embryogenic calli on media with several levels of $\mathrm{NaCl}$. They reported that unselected and selected salt tolerant callus lines showed marked differences in their growth curves and salt tolerance. The maximum level of tolerance achieved completely inhibited the growth of the unselected line.

Garcia-Agustin and Primo-Millo (1992) regenerated plants from ovular callus of Troyer citrange, which were subjected to EMS. Nucellus tissue cultured to induce embryoids and plantlets were regenerated and the regenerated plants were then exposed to $45 \mathrm{mM} \mathrm{NaCl}$. These possible mutants were selected and propagated by cuttings and were exposed to increasing salinity levels. The selected plants showed better growth, less leaf damage and lower $\mathrm{Cl}^{-}$and $\mathrm{Na}^{+}$, but higher $\mathrm{K}^{+}$leaf levels 
than the wild type. They further reported the recovery of an NaCl-tolerant plant of Troyer citrange, which grew faster, accumulated more $\mathrm{Na}^{+}$in shoots and roots and significantly reduced the $\mathrm{Na}^{+}$concentration in leaves (Garcia-Agustin \& Primo-Millo, 1995). Similarly, Spiegel-Roy \& Saad (1997) reported that in green house experiments plants from a tolerant cell line $\left(\mathrm{R}_{14}\right)$, irrigated with saline water (up to $2000-2500 \mathrm{mg} \mathrm{Cl} /$ litre) were taller and had a higher plant survival rate compared to the wild line.

Piqueras et al. (1996) reported that there are changes in antioxidant enzymes and organic solutes associated with adaptation of citrus cells to salt stress. The selected callus accumulated more $\mathrm{Na}^{+}$and $\mathrm{Cl}^{-}$than the nonselected one. Amounts of proline and total sugars, mainly sucrose, were higher in tolerant selected lines, which also had higher choline and glycine-betaine concentrations.

Wanas et al. (1999) screened seedlings from five rootstocks in vitro. The seedlings were subcultured at 4-week intervals on solid or liquid MS media containing progressively increasing concentrations (0-5000 ppm) of a mixture of $\mathrm{NaCl}_{1} \mathrm{CaCl}_{2}$ and $\mathrm{MgCl}_{2}$. Seedlings demonstrated a progressive degree of adaptation to salinity as they were subcultured. Plantlets, which survived exposure to $5000 \mathrm{ppm}$ salinity in vitro survived exposure to $4000 \mathrm{ppm}$ salinity in the sand culture.

Singh (2000) screened citrus rootstocks under in vivo and in vitro conditions. Under both types of conditions Rangpur lime exhibited a tolerance to salinity. However, under in vitro conditions, less callus browning, low $\mathrm{Na}^{+}$and $\mathrm{Cl}^{-}$uptake and lower Na:K ratio in callus were suggested to be reliable criteria for screening of citrus rootstocks for salt tolerance.

\section{REFERENCES}

Abbadi, S. 1969. Growth characteristics of new Citrus rootstocks of possible potential in Sudan. Indian Journal of Horticulture 26: 1-14.

Abdel-Messih, M.N., Rokba, A.M., El-Shourbagy, M.A. \& El-Nokrashy, M.A. 1979. Effect of different salinity levels on leaf mineral composition of some citrus stock seedlings. Egyptian Journal of Horticulture 6: 81-89.

Aljuburi, H. 1996. Effect of saline water on growth parameters of five citrus rootstocks. Annals of Arid Zone 35: 43-48.

Alva, A.K. \& Syvertsen, J.P. 1991. Irrigation water salinity affects soil nutrient distribution, root density and leaf nutrient levels of citrus under drip fertigation. Journal of Plant Nutrition 14: 715-727.

Attalla, A.M. 1987. Testing some new introduced citrus rootstocks for salt tolerance in Egypt. Alexandria Journal of Agricultural Research 32: 219-230.

Badawi, A.M., Barakat, M.R., El-Kholi, A.F. \& Ragab, M.A. 1979. Effect of the combined microelements (Fe, Mn or B) and sodium chloride salt treatments on sour orange seedlings. Ain Shams University Faculty of Agriculture Bulletin No. 1107: $16 \mathrm{pp}$.

Bahodyrov, M. 1956. The use of saline soils for mulberry cultivation. Tr. Taskentsk.s-h-In-ta 7: 77-86.

Banuls, J. \& Primo-Millo, E. 1995. Effects of salinity on some citrus scion-rootstock combinations. Annals of Botany 76: 97102.

Banuls, J., Legaz, F. \& Primo-Millo, E. 1990. Effect of salinity on uptake and distribution of chloride and sodium in some citrus scion-rootstock combinations. Journal of Horticultural Science 65: 715-724.

Banuls, J., Serna, M.D., Legaz, F., Talon, M. \& Primo-Millo, E. 1997. Growth and gas exchange parameters of citrus plants stressed with different salts. Journal of Plant Physiology 150: 194-199.

Beeftink, W.G. 1955. Examination of soils and crops after the inundations of 1st Feb. 1953. III. Sensitivity to salt of inundated fruit crops. Netherlands Journal of Agricultural Science 3: 15-34.

Behboudian, M.H., Torokfalvy, E. \& Walker, R.R. 1986. Effects of salinity on ionic content, water relations and gas exchange parameters in some citrus-rootstock combinations. Sci Hort-Amsterdam 28: 105-116.

Ben-Hayyim, G. \& Goffer, Y. 1989. Plantlet regeneration from a NaCl-selected salt tolerant callus culture of Shamouti orange (Citrus sinensis [L.] Osbeck). Plant Cell Reports 7: 680-683.

Ben-Hayyim, G. \& Kochba, J. 1982. Growth characteristics and stability of tolerance of citrus cells subjected to $\mathrm{NaCl}$ stress. Plant Science Letters 27: 87-94.

Ben-Hayyim, G. \& Kochba, J. 1983. Aspects of salt tolerance in a NaCl-selected stable cell line of Citrus sinensis. Plant Physiology 72: 685-690.

Ben-Hayyim, G., Spiegel-Roy, P. \& Neumann, H. 1985. Relation between ion accumulation of salt sensitive and isolated stable salt-tolerant cell lines of Citrus aurantium. Plant Physiology 78: 144-148. 
Bhambota, J.R. \& Kanwar, J.S. 1968, 1969. Salinity tolerance of some rootstocks and scions of Citrus species. Proceeding of 1st International Citrus Symposium Riverside 3: 1833-1836.

Bhambota, J.R. and Kanwar, J.S. 1970. Effect of different salt concentrations on sweet orange (Citrus sinensis L. Osbeck). Indian Journal of Agricultural Science 40: 485-494.

Bielorai, H., Dasberg, S., Erner, Y. \& Brum, M. 1988. The effect of saline irrigation water on Shamouti orange production. Proceeding of $6^{\text {th }}$ International Citrus Congress of Middle-East, Tel Aviv, Israel. 6-11 March 2: 707-715.

Bielorai, H., Shalhevet, J. \& Levy, Y. 1983. The effect of high sodium irrigation water on soil salinity and yield of mature grapefruit orchards. Irrigation Science 4: 255-266.

Boman, B.J. 1994. First year response of 'Ruby Red' grapefruit on four rootstocks to fertilization and salinity. Proceeding of Flaricla State Horticulture Society 106: 12-18.

Buffum, B.S. 1896. Wyoming Agricultural Evperiment Station Bulletin 29 (From Alkali and Saline Soils, U.S. Handbook 1960. pp. 62).

Caro, M., Cerda, A., Fernandez, F.G. \& Guillen, M.G. 1973. The tolerance of citrus rootstocks to salinity during germination. In: International Congresso Mundial de Citricultura 1: 313-316.

Cerda, A., Caro, M.,; Fernandez, F.G. \& Guillen, M.G. 1986. Effect of irrigation water quality on Verna lemon response and soil salinity. Agrochimica 30: 207-217.

Chapman, H.D., Joseph, H. \& Rayner, D.S. 1969. Effects of variable maintained chloride levels on orange growth, yield and leaf composition. Proceeding of 1st Internation Citrus Symposium, Riverside 3: 1811-1817.

Chen, Z., Nil, H., Ji, Y., Gan, J. \& Wu, Y. 1990. Identification of salt tolerance of some kind of citrus biotypes. Proceeding of 1st International Citrus Symposium, Guangzhou, China 5-8 Nov: 271-275.

Cherif, D., Zid, E., Ayadi, A. \& Thellier, M. 1981. The effect of sodium chloride on the growth and mineral nutrition of Citrus aurantium (sour orange) and the hybrid Poncirus trifoliata $\mathrm{x}$ Citrus sinensis (Troyer citrange). Comptes Rendus des Seances de 1' Academie des Sciences, III. Sciences de la Vie 292: 879-882.

Cole, P.J. \& McCloud, P.I. 1985. Salinity and climatic effects on the yields of citrus. Australian Journal of Experimental Agriculture 25: 711-717.

Cooper, W.C. 1961, 1962. Toxicity and accumulation of salts in citrus trees on various rootstocks in Texas. Proceeding of Florida State Horticulture Society 74: 94-104

Cooper, W.C. \& Peynado, A. 1953. A comparison of sour orange and Cleopatra mandarin seedlings on salty and calcareous nursery soils. Proc. $7^{\text {th }}$ Annu. Rio Grande Vall. Hort. Inst. pp. 95-101.

Cooper, W.C., Gorton, B.S. \& Edwards, C. 1951a. Salt tolerance of various citrus rootstocks. Proc. $5^{\text {th }}$ Annu. Rio Grande Vall. Hort. Inst. pp. 46-52.

Cooper, W.C., Gorton, B.S. \& Olson, E.O. 1951b. Ion accumulation in citrus as influenced by rootstock and scion and concentration of salts and boron in the substrate. Plant Physiology 26: 191-203.

Cooper, W., Olson, E.O. \& Otey, G. 1956. Review of studies on adaptability of citrus varieties as rootstocks for grapefruit in Texas. J. Rio Grande Vall. Hort. Soc. 10: 6-19.

Dasberg, S., Bielorai, H. \& Erner, Y. 1988a. The effect of saline irrigation water on Shamouti oranges. Acta Hort. No. 228: 305-316.

Dasberg, S., Bielorai, H., Erner, Y., Brum, M.; Cohen, S. \& Nadler, A. 1985. The effect of saline irrigation water on Shamouti oranges. Alon Hanotea 40: 35-42.

Dasberg, S., Bielorai, H., Haimowitz, A., Erner, Y. \& Brum, M. 1988b. The effect of saline irrigation water on Shamouti orange production in the coastal plains. Alon Hanotea 43: 53-61.

de Boxio. 1963. A check on the $\mathrm{NaCl}$ content of the soils of Cheraia and Onled Othman carried out from 5-8 April, 1962. E.R Académia d'Agriculture 49: 416-417.

Deng, Z.N., Zhang, W.C. \& Wan, S.Y. 1989. In vitro mutation breeding for salinity tolerance in citrus. Mutation Breeding Newsletter No. 33: 12-14.

Deng, Z.N., Zhang, W.C. \& Wan, S.Y. 1990. In vitro induction, biochemical analysis and protoplast plant regeneration from NaCl-tolerant lines in citrus. Proceeding of International Citrus Symposuinm. Guangzhou, China, 5-8 Nov. pp. 263-270.

Devjatov, A.D. 1961. Variations in the salt tolerance of woody plants in the course of ontogeny. Botaniceskij Zurnal 46: 3950.

Duke, E.R., Johnson, C.R. \& Koch, K.E. 1986. Accumulation of phosphorus, dry matter and betaine during $\mathrm{NaCl}$ stress of 
split-root seedlings colonized with vesicular-arbuscular mycorrhizal fungi on zero, one or two halves. New Physiologist 104: 583-590.

El-Desouky, S.A. and Atawia, A.A.R. 1998. Growth performance of some citrus rootstocks under saline conditions. Alexandria Journal of Agricultual Research 42: 231-254.

El-Hammady, A.M., Abou-Rawash, M., Abou-Aziz, A., Abdel-Hamid, N. \& Abdel-Moneim, E. 1995. Impact of irrigation with salinized water on growth and mineral content of some citrus rootstock seedlings. Ann. Agric. Sci. (Cairo) 40: 327-341.

El-Kholi, A.F., Barakat, M.R., Badawi, A.M. \& Ragab, M.A. 1979a. Effect of various chloride salts on growth and mineral content of Valencia orange. Ain Shams University Faculty of Agriculture Bulletin No. 1106: 15 pp.

El-Kholi, A.F.; Barakat, M.R; Badawi, A.M. \& Ragab, M.A. 1979b. Sour orange seedlings as affected by saline water. Ain Shams University Faculty of Agriculture Bulletin No. 1108: 15.

Fernandez-Ballester, G., Martinez, V., Ruiz, D. \& Cerda, A. 1998. Changes in inorganic and organic solutes in citrus growing under saline stresses. Journal of Plant Nutrition 21: 2497-2514.

Francois, L.E. \& Clark, R.A. 1980. Salinity effects on yield and fruit quality of 'Valencia' orange. Journal of the American Society for Hortichltural Science 105: 199-202.

Furr, J.R. \& Ream, C.L. 1968. Breeding and testing rootstocks for salt tolerance. California Citrograph 54: 30-35.

Furr, J.R., Carpenter, J.B. \& Hewit, A.A. 1963. Breeding new varieties of Citrus fruits and rootstocks for the south west. J. Rio Grande Vall. Hort. Sci. 17: 90-107.

Gallasch, P.T. \& Dalton, G.S. 1989. Selecting salt-tolerant citrus rootstocks. Australian Journal of Agricultural Research, 40: 137-144.

Garcia-Agustin, P. \& Primo-Millo, E. 1992. Selection for NaCl-tolerance of Troyer citrange. Proc. Intern. Soc. Citric. 1: 404414.

Garcia-Agustin, P. \& Primo-Millo, E. 1995. Selection of a NaCl-tolerant citrus plant. Plant Cell Reports 14: 314-318.

Garcia-Legaz, M.F., Garcia-Lidon, A., Porras Castillo, I. \& Ortiz Marcide, J.M. 1994. Behaviour of different scion/stock combinations of lemons[C. limon (L.) Burm. f.] against Cl- and Na+ ions. Proc. Intern. Soc. Citric. 1: 397-399.

Garcia-Legaz, M.F., Ortiz, J.M., Garcia-Lidon, A.G. \& Cerda, A. 1993. Effect of salinity on growth, ion content and $\mathrm{CO}_{2}$ assimilation rate in lemon varieties on different rootstocks. Physiologia Plantarum 89: 427-432.

Garcia-Lidon, A., Ortiz, J.M., Garcia-Legaz, M.F. \& Cerda, A. 1998. Role of rootstock and scion on root and leaf ion accumulation in lemon trees grown under saline conditions. Fruits (Paris) 53: 89-97.

Goell, A. 1969. Salinity effects on citrus tress. Proc. 1st Intern. Citrus Symp., Riverside 3: 1819-1824.

Grieve, A.M. 1983. Salt uptake by citrus trees. Australian Citrus News 59(Nov.): 3, 8.

Grieve, A.M. \& Walker, R.R. 1983. Uptake and distribution of chloride and potassium in salt treated plants. Australian Journal of Agricultural Science 34: 133-143.

Guillen, M.G., Caro, M., Fernandez, F.G. \& Cerda, A. 1978. Foliar composition of citrus seedlings irrigated with saline water. Communications in Soil Science and Plant Analysis 9: 595-606.

Harahap, R. 1984. Tolerance of citrus seedlings to sodium chloride. Ilmu Pertanian 3: 285-289.

Hassan, M.M. \& Galal, M.A. 1989. Salt tolerance among some citrus rootstocks. J. King Saud Univ. Agric. Sci. 1: 87-93.

Hilgard, E.W. 1900. Nature, value \& utility of alkali lands. University of California Agriculture Experiment Station Bulletin 128: $1-46$.

Holevas, C.D. and Demetrisdes, S.D. 1963. Citrus tree injuries caused by Cl toxicity. Annales de L'Institut Phytopathologique Benaki 5: 135-148.

Howie, H. \& Lloyd, J. 1989. Response of orchard 'Washington Navel' orange, Citrus sinensis (L.) Osbeck, to saline irrigation water. II. Flowering, fruit set and fruit growth. Australian Journal of Agricultural Science 40: 371-380.

Hutchinson, D.J. 1974. Swingle citrumelo - a promising rootstock hybrid. Proceeding of Florida State Horticulture Society 87: 89-91.

Joolka, N.K. \& Singh, J.P. 1979. Effect of soil salinity on the growth of citrus rootstocks. Indian Journal of Agricultural Science 49: 858-861.

Joolka, N.K., Singh, J.P. \& Khera, A.P. 1980. Effect of saline irrigation water on the growth of sweet orange plants (Citrus sinensis Osbeck). Haryana Journal of Horticultural Science 9: 125-128.

Khanna, R.C. \& Kumar, R.J. 1990. Effect of salinity levels on the growth of Nagpur mandarin (Citrus reticulata Blanco). Indian Journal of Horticulture 47: 190-193. 
Kirkpatrick, J.D. \& Bitters, W.P. 1969. Physiological and morphological response of various citrus rootstocks to salinity. Proc. 1st Intern. Citrus Symp., Riverside 1: 391-399.

Kochba, J. \& Spiegel-Roy, P. 1980. Progress in selection for sodium chloride, 2, 4-D and streptomycin tolerance in Citrus sinensis ovular callus lines. In: Induced mutations in vegetatively propagated plants I/. Coimbatore, India. 11-15 Feb.: 77 89.

Kochba, J., Ben-Hayyim, G., Spiegel-Roy, P., Saad, S. \& Neumann, H. 1982. Selection of stable salt tolerant cell lines and embryos in Citrus sinensis and C. aurantium. Zeitoschrift fur Pflanzenphysiologie 106: 111-118.

Lea-Cox, J.D. \& Syvertsen, J.P. 1993. Salinity reduces water use and nitrate-N-use efficiency of citrus. Annals of Botany 72: 47-54.

Levy, Y., Lifshitz, J., Malach, Y. de \& David, Y. 1999.The response of several Citrus genotypes to high salinity irrigation water. Hort Science 34: 878-881.

Levy, Y., Shalhevet, J. \& Lifshitz, J. 1992. The effect of salinity on citrus rootstocks and scions. In: Proc. Intern. Soc. Citriculture 1: 391-396.

Lloyd, J. \& Howie, H. 1989. Response of orchard 'Washington Navel' orange, Citrus sinensis (L.) Osbeck, to saline irrigation water 1. Canopy characteristics and seasonal patterns in leaf osmotic potential, carbohydrates and ion concentrations. Australian Journal of Agricultual Research 40: 359-369.

Loughridge, R.H. 1900. Effect of alkali on citrus trees. University of California Agriculture Station Report 1897-98: 99-113.

Maas, E.V. 1992. Salinity and Citriculture. In: Proc. Intern. Soc. Citriculture 3: 1290-1301.

Matsumoto, K. \& Yamaguchi, H. 1984. Increased variation of NaCl-tolerance in adventitious embryoids of trifoliate orange using in vitro technique. Revista Brasileira de Genetica 7: 73-81.

Mobayen, R.G. \& Milthorpe, F.L. 1978. Citrus seed germination as influenced by water potential and salinity. In: Proc. Intern. Soc. Citriculture: 247-249.

Mobayen, R.G. \& Milthorpe, F.L. 1980. Response of seedlings of three citrus rootstock cultivars to salinity. Australian Journal of Agricultural Research 31: 117-124.

Nastou, A., Chartzoulakis, K., Therios, I. \& Bosabalidis, A. 1999. Leaf anatomical responses, ion content and $\mathrm{CO}_{2}$ assimilation in three lemon cultivars under $\mathrm{NaCl}$ salinity. Advances in Horticulture Science 13: 61-67.

Newcomb, D.A. 1978. Selection of rootstocks for salinity and disease resistance. In: Proc. Intern. Soc. Citriculture 117-120.

Nieves, M., Cerda, A. \& Botella, M. 1991. Salt tolerance of two lemon scions measured by leaf chloride and sodium accumulation. Journal of Plant Nutrition 14: 623-636.

Nieves, M., Ruiz, D. \& Cerda, A. 1992. Influence of rootstock scion combinations in lemon trees salt tolerance. In: Proc. Intern. Soc. Citriculture 1: 387-390.

Patil, V.K. \& Bhambota, J.R. 1978. Growth behaviour of certain citrus rootstocks as influenced by different levels of salinity in soil. Haryana Journal of Horticultural Science 7: 105-111.

Peynado, A. \& Young, A. 1969. Relation of salt tolerance to cold hardiness of 'Redblush grapefruit' and 'Valencia orange' trees on various rootstocks. In: Proc. 1st Intern. Citrus Symp. 3: 1793-1802.

Piqueras, A. \& Hellin, E. 1992. Selection and characterization of a NaCl-tolerant cell line of Citrus limonum. Sueloy Planta 2: 629-640.

Piqueras, A, Hernandez, J.A., Olson, E., Hellin, E. \& Sevilla, F. 1996. Changes in antioxidant enzymes and organic solutes associated with adaptation of citrus cells to salt stress. Plant Cell, Tissue and Organ Culture 45: 53-60.

Ream, C.L. \& Furr, J.R. 1976. Salt tolerance of some Citrus species, relatives and hybrids tested as rootstocks. Journal of the American Society for Horticultural Science 101: 265-267.

Rokba, A.M., Abdel-Messih, M.N. \& Mohamed, M.A. 1979. Breeding and screening some citrus rootstocks for salt tolerance in Egypt. Egyptian Journal of Horticulture 6: 69-79.

Ruiz, D., Martinez, V. \& Cerda, A. 1997. Citrus response to salinity : Growth and nutrient uptake. Tree Physiology 17: 141150.

Ruiz, D., Martinez, V. \& Cerda, A. 1999. Demarcating specific ion $\left(\mathrm{NaCl}, \mathrm{Cl}^{-}\right.$and $\left.\mathrm{Na}^{+}\right)$and osmotic effects in the response of two citrus rootstocks to salinity. Sci Hort-Amsterdam 80: 213-214.

Salem, A.T. \& El-Khorieby, M.K. 1989. Response of citrus rootstocks to different types of chloride salt treatments. Annals of Agricultural Science 34: 1123-1127.

Salerno, M. 1975. Salt damage in apulia. Italia Agricola 112: 94-101. 
Shalhevet, J., Yaron, D. \& Horowitz, U. 1974. Salinity and citrus yield- an analysis of results from a salinity survey. Journal of Horticultural Science 49: 15-27.

Singh, Awtar 2000. Screening of citrus rootstocks for salt tolerance at seedling and callus level. Unpublished Ph. D. Thesis. CCS HAU, Hisar.

Singh, Awtar., Srivastava, A.K., Dass, H.C. \& Vijayakumari, N. 1997. Screening of germplasm of citrus rootstocks for salinity tolerance. Indian Journal of Horticulture 54: 283-287.

Spiegel-Roy, P. \& Ben-Hayyim, G. 1985. Selection and breeding for salt tolerance in vitro. Plant and Soil 89: 243-252.

Spiegel-Roy, P. \& Saad, S. 1997. Regeneration from salt tolerant callus in citrus. Advances in Horticulture Science 11: 3-9.

Srivastava, A.K., Kohli, R.R., Lallan Ram \& Dass, H.C. 1998. Relationship between chloride accumulation in leaf and cationexchange capacity of roots of Citrus species. Indian Journal of Agricaltural Science 68: 39-41.

Storey, R. \& Walker, R.R. 1999. Citrus and salinity. Sci Hort-Amsterdam 78: 39-81.

Sykes, S.R. 1992. The inheritance of salt exclusion in woody perennial fruit species. Plant Soil 146: 123-129.

Syvertsen, J.P., Lloyd, J. \& Kriedemann, P.E. 1988. Salinity and drought stress effects on foliar ion concentration, water relations and photosynthetic characteristics of orchard citrus. Australian Journal of Agricultural Science 39: 619-627.

Walker, R.R. 1986. Sodium exclusion and potassium selectivity in salt stressed trifoliate orange (Poncirus trifoliata) and Cleopatra mandarin (Citrus reticulata) plants. Australian Journal of Plant Physiology 13: 293-303.

Walker, R. R. \& Douglas, T.J. 1983. Effect of salinity level on uptake and distribution of chloride, sodium and phosphorus ions in citrus plants. Australian Journal of Agricultural Research 34: 145-153.

Walker, R.R., Blackmore, D.H. \& Sun, Q. 1993. Carbondioxide assimilation and foliar ion characteristics in leaves of lemon (Citrus limon L.) trees irrigated with $\mathrm{NaCl}$ or $\mathrm{Na}_{2} \mathrm{SO}_{4}$. Australian Journal of Plant Physiology 20: 173-185.

Walker, R.R., Torckfalvy, F., Grieve, A.M. \& Prior, L.D. 1983. Water relations and ion concentrations of leaves on saltstressed citrus plants. Australian Journal of Plant Physiology 10: 265-277.

Wanas, Walfaa, H., El-Hammady, A.M., Tadrous, M.R. \& El-Habashy, S. 1999. In vitro evaluation and adaptation to progressive salt stress for some citrus rootstock seedlings. Ann. Aagric. Sci. (Cairo) 44: 689-704.

Zekri, M. 1991. Effects of $\mathrm{NaCl}$ on growth and physiology of sour orange and Cleopatra mandarin seedlings. Sci Hort-Amsterdam 47: 305-315.

Zekri, M. 1993a. Osmotic and toxic ion effects on seedlings emergence and nutrition of citrus rootstocks. Journal of Plant Nutrition 16: 2013-2028.

Zekri, M. 1993b. Salinity and calcium effects on emergence, growth and mineral composition of seedlings of eight citrus rootstocks. Journal of Horticultural Science 68: 53-62.

Zekri, M. 1993c. Seedling emergence, growth and mineral concentration of three citrus rootstocks under salt stress. Journal of Plant Nutrition 16: 1555-1568.

Zekri, M. 1994. Effects of salinity and calcium on seedling emergence, growth and sodium and chloride concentrations of citrus rootstocks. Proceeding of Florida State Horticulture Society 106: 18-21.

Zekri, M. \& Parsons, L.R. 1989. Growth and root hydraulic conductivity of several citrus rootstocks under salt stress and polyethylene glycol stresses. Physiologia Plantarum 77: 99-106.

Zekri, M. \& Parsons, L.R. 1990a. Calcium influences growth and leaf mineral concentrations of citrus under saline conditions. Hort Science 25: 784-786.

Zekri, M. \& Parsons, L.R. 1990b. Comparative effects of $\mathrm{NaCl}$ and polyethylene glycol on root distribution, growth and stomatal conductance of sour orange seedlings. Plant and Soil 129: 137-143.

Zid, E. \& Grignon, C. 1986. Comparative effects of $\mathrm{NaCl}, \mathrm{KCl}$ and $\mathrm{Na}_{2} \mathrm{SO}_{4}$ on the growth and mineral nutrition of young Citrus aurantium L. Acta Oecologia, Oecologia Plant 7: 407-416. 